\title{
The Implementation of Transition Programme for Students with Learning Disabilities in Malaysia
}

\author{
Mohd Syazwan Zainal, Harwati Hashim \\ Faculty of Education, Universiti Kebangsaan Malaysia, Bandar Baru Bangi, Malaysia \\ Email: syazwanzainal@ukm.edu.my
}

How to cite this paper: Zainal, M. S., \& Hashim, H. (2019). The Implementation of Transition Programme for Students with Learning Disabilities in Malaysia. Creative Education, 10, 1802-1812. https://doi.org/10.4236/ce.2019.108129

Received: May 27, 2019

Accepted: August 4, 2019

Published: August 7, 2019

Copyright $\odot 2019$ by author(s) and Scientific Research Publishing Inc. This work is licensed under the Creative Commons Attribution International License (CC BY 4.0).

http://creativecommons.org/licenses/by/4.0/

\section{(c) (i) Open Access}

\begin{abstract}
This case study was conducted to look into the implementation of transition programme for students with learning disabilities in the special education integration programmes. This study employed qualitative research design involving three special education teachers in a school located in a city in Malaysia and data were obtained through interviews. The findings show that a successful transition programme in the school covers various levels. Vocational training is also provided to pupils to prepare them for career training. This study also found that there is a cooperative relationship between school administrators, families, institutions of higher learning and employers who are willing to cooperate in providing transitional programmes to students with learning disabilities. The discussion and recommendations of future studies are described further in the writing of this article.
\end{abstract}

\section{Keywords}

Students with Learning Disabilities, Special Education, Career Transition, Vocational Training, Collaboration

\section{Introduction}

Since the 1980s, studies have found that there is an incredible amount that is achieved by individuals with learning disabilities in obtaining employment after completing schooling. US Commission on Civil Rights (1983) found that 75\% of adults with learning problems across the United States were unemployed. Other studies have found similar results (Hasazi, Gordon, \& Roe, 1985; Kiernan \& Stark, 1989; Wehman, Kregel, \& Seyfarth, 1985; Wehman, Kregel, \& Barcus, 1985). Therefore, in the 1990s policymakers began to pay more attention to the 
provision of disabled students to post-school life.

The Individuals with Disabilities Education Act (IDEA, 2004) states that transitional services should be provided to pupils at the age of 16 and above to provide them with life after school. However, studies have suggested that IDEA started the transition process to students at the age of 14 years old. It is assumed that two years of additional transitional services that begin at the age of 14 will increase the results enjoyed by students with learning disabilities in the vocational field to provide them to the career market. A study has been conducted to view the success of the transition programme undertaken by two groups of autism students involved in vocational programmes. In the study, a group initiated a transition programme starting from the age of 16 while another group started at the age of 14 . The study found that the groups who started the transition programme earlier than 14 years are able to get jobs easier after they completed schooling (Cimera, Burgess, \& Wiley, 2013). Due to that, this study aims to review the implementation of transition programme among students with learning disabilities at schools; review how vocational training is provided to the students; and, look into the cooperation between the various parties in the implementation of the transition programme with schools.

\section{Literature Review}

\subsection{Vocational Education for Students with Learning Disabilities in Malaysia}

In Malaysia, transformation of vocational education was initiated in 2013 provides for a change in providing trained and skilled workforce to meet the nation's demand for entry into the job market. Vocational education for students with special needs in terms of learning disabilities is not left behind. Based on 2012 statistics, the number of pupils with learning disabilities in high school is 19,462 (Department of Special Education, 2012). The arising amount of the need for the Education Ministry (KPM), especially the Special Education Division to create a curriculum based on vocational training skills for learning disabled students is an alternative to the existing curriculum to ensure they are also largely included (Zainudin, 2008). A study by Ramlee (2004) shows that vocational education is a prerequisite for preparing students with specific needs to compete in the job market.

Vocational education for students with special needs is introduced to meet the needs of the curriculum that is more flexible, focused, attractive and compatible with the needs and abilities of special needs students in assisting them to acquire certain skills (Department of Special Education, 2005). Through vocational education, special needs pupils can use the skills acquired to become more independent either for employment or to use skills to engage in business and entrepreneurship. Previous findings indicate that the curriculum structure accompanied by career experience training, vocational education and work goals are the indicators for better job creation (Fabian et al., 2007). Therefore, it must be at par 
with the student's intellectual ability and can emphasize the aspect of building students' positive attitude towards the curriculum absorbing the existing content to acquire the aforementioned specific skills. The introduction of a special vocational curriculum involves the planning aspect of teacher availability.

Special vocational curriculum should also pay attention to the aspect of cooperation. Zainudin (2008) in his study shows that collaboration with the community in education is very important to improve the group's skills and careers with specific needs. A special vocational curriculum for students with learning disabilities needs to be specifically tailored to expose students involved with social skills, career counseling, improve self-esteem, free living, vocational training, job adaptation, reading and spelling, organizing and administering financial, moral aspects entrepreneurship and self-reliant skills that are key to success in career (Sitlington \& Clark, 2006).

Domzal, Houtenville, and Sharma (2008) stated that employers are reported to be less interested in hiring people with disabilities due to lack of job skills. The weaknesses seen in many educational institutions are poor preparation for pupils with special needs which include the inability to provide them with the right job skills to meet the needs of employers (Zainudin et al., 2009). Collaboration between service providers and communication as well as partnerships between parents, companies, community agencies, teachers and others in schools are the key to the success of vocational training and career-based transition activities (Kohler \& Field 2003; Landmark et al., 2010).

\subsection{Collaboration of Various Agencies in Assisting Transition Programmes}

According to Kohler (1996) in the Transition Taxonomic Model, collaboration among various agencies is a key element in the success of the transition programme. Collaboration was established as a service delivery system with roles, responsibilities, communication strategies, and other cooperation measures aimed at developing curriculum and system development and service delivery systems (Benz, Lindstrom, \& Yovanoff, 2000; Kohler, 1996). The purpose of this collaborative activity is to implement an integrated system that addresses the lifelong learning and support needs of community members. Devlieger \& Trach (1999) found collaboration and inter-agency support for pupils in the transition programme was an important factor, facilitating the achievement of a defined transition goal.

Inter-agency collaboration does not only expose students to the community but also provides a direct and meaningful career training experience for students (Kohler \& Field, 2003). The career preparation experience is designed to help young people prepare and succeed after school education, career and independence. Preparatory activities for career experience include career awareness activities, career exploration, career assessment in teaching and learning, job skills and career-based training to provide students with opportunities to explore various careers and identify career interests (Blackmon, 2008). 
The transition to adult models by Blackmon (2008), states that agencies should serve every student as individuals and are committed to meeting the needs of each student by determining the types of services and agencies involved. Inter-agency co-operation is important to provide students with learning disabilities, especially for community-based collaboration. Landmark, Ju, and Zhang (2010) recommended helping students gain maximum benefit and be able to practice skills in a variety of environments, school-based experiences and community-based experiences including working environment should be exposed to students.

Johnson et al. (2002) states that the provision of school programmes and community-based careers experience should be implemented as one of the factors that help students succeed in the workplace. Previous studies have shown that collaboration between agencies is very important for students with special needs. The study by Zainudin (2004) found that collaboration with the community in education was also crucial to improve the group's skills and careers with special needs. The community or groups in their studies involve governments, non-governmental organizations, employers and individuals.

In this case, various parties include school administrators, teachers, parents, community agencies and communities (Landmark et al., 2010; Noonan et al., 2012; Zhang et al., 2005) should be effectively collaborating. Based on the above study, it is clear that the collaboration of special education teachers by creating inter-agency cooperation is a preliminary preparation for those with special needs to enter the career. Collaboration and cooperation among listed agencies is an effective practice to facilitate transition programmes based on vocational training for disadvantaged learners facing their adult life after they completed their schooling years.

\section{Methodology}

This study employed a qualitative approach using case study design. This study involved interviews with three respondents, namely special education teachers at a secondary school in a state in Malaysia. The qualitative approach is based on the assumption that, the meaning or reality of a phenomenon is socially constructed by the perpetrators involved in the phenomena studied. Every meaning or knowledge gained in qualitative studies is holistic, multi-dimensional and dynamic (Merriam, 2009). The selected research design helps the researcher get more detailed information on the subject. According to Creswell (2012); Johnson and Christensen (2000), the conduct of qualitative studies typically does not have a standardized procedure that meets the expectations and needs of all parties.

In this study, interviews require informants to obtain rich data based on research questions and simultaneously submit friendly questions and do not interfere with Yin's (2008) threat and pressure. Three main questions were asked in this study are which are:

1) How does a career transition program apply to special needs students? 
2) How does vocational training be provided to all students at school?

3) How does collaboration between different parties make a career transition program successful?

In addition, researchers also used "probing" questions which could provide more information to obtain richer data and information such as "Can you please explain further?" and "Why do think so?". Patton (2002) explains that "probing" is aimed at increasing the richness of data as well as obtaining more clarity or understanding of the phenomena being studied. The researchers used probing technique to encourage participants to provide a detailed description of the experience, learning and all matters related to research questions. In addition, probing is also used to obtain certainty and clarity by applying examples for a particular item specified by the study participants.

\section{Findings}

The findings are discussed based on the following three areas:

1) Implementation of transition programmes in schools among students with learning disabilities;

2) Implementation of vocational training provided to students with learning disabilities; and,

3) Cooperation between various parties in implementing transition programmes for students with learning disabilities.

\subsection{Implementation of Transition Programmes}

Data from the research sample can be summarized on several points:

1) Be aware of the importance and necessity of the transition programme from school to adult life for students with special needs, all of these students are given the opportunity to undergo a career transition process through a programme designed specifically by the school.

2) All students have the opportunity to be involved in learning the required work skills but it will look at the student's level or ability.

3) The school has devised 5 transition programme methods that can be used for all special education students in the school who have learning problems:

a) Method A: Field work is a career visit to industry and enterprise.

b) Method B: Transitional support projects such as interpersonal and personality skills training.

c) Method C: Internal work training i.e., vocational training.

d) Method D: Exercise skills training centre such as skills college.

e) Method E: Exercise work outsourcing i.e. career in the workplace.

All students have the opportunity to be involved in learning the required work skills but it depends on the student's level or ability.

4) Employers who provide career practitioners in their premises.

Based on these findings, it can be concluded that all special education students with learning disabilities in this school are given a career transition training ac- 
cording based on their ability.

\subsection{Implementation of Vocational Training}

Through the interviews conducted, several aspects can be determined to prove that vocational training is given to students with learning disabilities such as:

1) In-house training provided by the school through classroom-based activities such as workshop and class management, managing tools and timetables of work activities.

2) Vocational training includes the school's syllabus such as cooking skills and sewing skills.

3) Vocational training is given to students who have achieved the best level in the training centre outside of the school in the aspects of food and drinks serving, culinary basics and cooking skills as well as creative stitches.

The results of the interviews were found that vocational training was provided by teachers as well as skilled outsiders from relevant skills institution.

\subsection{Cooperation between Various Parties in Implementing Transition Programmes}

As a result of the interviews conducted with the three respondents, it can be concluded that:

1) The support given by the school administrator is very good. School administrators always provide incentives and support to the transition programme. Administrators have no obstacle in granting approval to all related programmes planned by teachers including out-of-school activities.

2) Parental support is also undeniable. There are also families who make the transition programme implemented at the school level by giving students the opportunity to practice career in the parent company. There are also parents who are also involved in the Welfare Committee for students here. In addition, parental support includes the activities of organizing talents through creative arts and horse-riding activities.

3) The involvement of a skill centre that provides facilities such as training, transportation and recognition to students who successfully complete a training programme.

4) Employers who are ready to give place to students who have reached the optimum level to carry out their career in the workplace.

Based on this finding, it can be concluded that there is a good cooperation between teachers, school administrators, families, skills training centres and employers. The collaboration is very important in providing transition programmes to problem-solving learners.

\section{Discussion}

School is a learning institution that is responsible for managing special needs education. The role of the school is to produce students who have self-advocacy for community life which is the transition from school to career. Therefore, the 
school should run a career transition programme for students with special needs. Based on the research conducted, the school administration is well-functioned to ensure that the planned career transition programme is planned. The school plays a role in ensuring the learning process of pupils in accordance with the rules and curriculum set. Through interviews and observations, special education teachers will play a role as a facilitator and act as a manager to enable students to be trained as an employee who can apply skills for well-being in the industry.

The success of the school in implementing the programme can be proven by sending students to undergo industrial training at the relevant place and pupils can be absorbed into permanent workers and remain employed. Based on the study, before industrial training is conducted, discussions will be made between three parties, namely school, parents and industry. Then all parties need to sign the agreement letter as a security measure. Schools will only serve as the monitors and assistants throughout the programme. Families and employers are responsible for managing student training programmes.

Implementation of vocational education for students with learning disabilities is an important agenda to be addressed by the government to improve the skills and capabilities of independence among students with learning disabilities. School is a place that provides an environment to develop the skills necessary to participate in society. All students, including students with learning disabilities should receive the learning convenience as well as experience and competencies needed to succeed in community life, employment and social experience (Morningstar et al., 2010). If people with special needs can benefit from specific capabilities that they have, they too can succeed like others to master certain skills more effectively.

At present, many job opportunities that can be filled by students with learning disabilities. This claim to the role of special education teachers to understand the concept of careers related to those with special needs. This statement shows that the education given to the special needs is to enable them to get jobs. Therefore, the cooperation of various parties such as school administrators, teachers, parents, government agencies and the private sector and the community is necessary to ensure that all plans that have been planned was accomplished successfully.

The collaboration between the active agencies with the school is due to the role played by this school that is constantly working to collaborate with relevant parties to ensure that vocational education can be successfully prepared as a preparation for a career experience for students with learning disabilities. The findings are in line with the study by Shafie (2002), Juairiah (2000), which states that having perfect support services will enable the curriculum to be implemented effectively.

This finding also suggests that students with learning disabilities learn to receive training especially in their self-management skills and teamwork skills so they can improve their confidence before they enter the career world. A study by 
Taylor (2005) states that training skills are essential as a preparation for individuals to compete in a working environment. This demonstrates that training skills need to be learned and then mastered by specific needs so they can have the opportunity to compete in the job.

The findings of this study support the findings by Singley (2003) stating that among the major obstacles for people with special needs for employment are the perceptions and negative attitudes of employers. In this case, employers cannot distinguish students from learning disabilities because these abilities are permanent. Instead, employers must see their abilities. Employers should also strive to understand the difficulty of learning so that pupils with learning disabilities are better prepared to receive their practical training and will have the opportunity to gain a job based on their skills.

Therefore, teachers should strive to highlight the talent and potential found in pupils of learning problems so that they can be accepted by employers. The next obstacle is the attitude of parents in implementing collaboration between agency and school. Previous studies found that parents are too busy with their own affairs that they have no time to engage with the activities organized by the school. The study by Sanbagavalli (2001) found that most parents involved in special education played a passive role in programmes outside the classroom. Therefore, parents need to play an important role in ensuring collaboration between agencies and schools can be implemented more effectively.

Parental involvement is identified as being able to promote social, emotional, physical, and academic aspects as well as enhancing employment skills among students. The success of family involvement gives a great deal to the cooperation between parents, pupils, school administrators and agencies involved (Blackmon, 2008; Grigal \& Neubert, 2004; Morningstar et al., 2010). Findings show that there are financial constraints and ease in providing vocational training outside the school area. Although vocational training has been provided within the school, pupils should also be exposed to industrial equipment and in practice training can only be provided at outside skills training centres.

In this case, schools need to work with parents and outsiders such as skills training centres to ensure that planned activities for students can be implemented successfully, especially in the implementation of vocational education. Thus, the collaboration between service providers and communication and partnerships between parents, companies, agencies within the community, teachers and school administrators is key to successfully implementing career transition and career development (Jamaliah, Rohana, \& Aede Hatib, 2012; Landmark, Ju, \& Zhang, 2010; Kohler \& Field, 2003).

\section{Conclusion}

In this case, schools need to work with parents and outsiders such as skills training centres to ensure that planned activities for students can be implemented successfully, especially in the implementation of vocational education. Thus, it could be concluded that the collaboration, communication and partnerships between ser- 
vice providers and parents, companies, agencies within the community, teachers as well as school administrators is the key to successful implementation of career transition and career development students with learning disabilities. In order to improve the quality of the career transition programme to students with special needs, the pre-emptive place for job training by outsiders needs to be enhanced. With this step, the school and parents can plan ahead to provide students with special needs to meet the needs at work. Further studies that can be conducted are to look at the impact on pupils after engaging with this transition programme. Various aspects can be seen including socio-emotional changes in the workplace, self-management, competence of working skills as well as student's ability to work.

\section{Conflicts of Interest}

The authors declare no conflicts of interest regarding the publication of this paper.

\section{References}

Benz, M. R., Lindstrom, L., \& Yovanoff, P. (2000). Improving Graduation and Employment Outcomes of Students with Disabilities: Predictive Factors and Students' Perspectives. Exceptional Children, 66, 509-529. https://doi.org/10.1177/001440290006600405

Blackmon, D. (2008). Transition to Adult Living: An Information and Resource guide. California Services for Technical Assistance and Training (CalSTAT California Department of Education 2008).

Cimera, R. E., Burgess, S., \& Wiley, A. (2013). Does Providing Transition Services Early Enable Students with ASD to Achieve Better Vocational Outcomes as Adults? Research and Practice for Persons with Severe Disabilities, 38, 88-93. https://doi.org/10.2511/027494813807714474

Creswell, J. W. (2012). Educational Research: Planning, Conducting, and Evaluating Quantitative and Qualitative Research (4th ed.). Boston, MA: Pearson.

Department of Special Education (2005). Maklumat Pendidikan Khas Malaysia. Kementerian Pendidikan Malasyia.

Department of Special Education (2012). Maklumat Pendidikan Khas Malaysia. Kementerian Pendidikan Malasyia.

Devlieger, P., \& Trach, J. (1999). Meditation as a Transition Process: The Impact on Post School Employment Outcomes. Exceptional Children, 65, 507-523. https://doi.org/10.1177/001440299906500406

Domzal, C., Houtenville, A., \& Sharma, R. (2008). Survey of Employer Perspectives on the Employment of People with Disabilities: Technical Report (Prepared under Contract to the Office of Disability and Employment Policy, U.S. Department of Labor). McLean, VA: Cherry Engineering Support Services.

Fabian, E. S., Lueking, R. G., \& Tilson, G. P. (2007). Employer and Rehabilitation Personnel Perspectives on Hiring Persons with Disabilities: Implication for Job Development. Journal of Rehabilitation, 61, 42-49.

Grigal, M., \& Neubert, D. A. (2004). Parent's in-School Values \& Post-School Expectations for Transition-Aged Youth with Disabilities. Career Development and Transition for Exceptional Individuals, 27, 65-85. 
https://doi.org/10.1177/088572880402700105

Hasazi, S. B., Gordon, L., \& Roe, C. A. (1985). Factors Associated with the Employment Status of Handicapped Youth Exiting High School from 1979 to 1983. Exceptional Children, 51, 455-469. https://doi.org/10.1177/001440298505100601

IDEA (2004). Individuals with Disabilities Education Act.

Jamaliah, M. J., Rohana, H., \& Aede Hatib, M. (2012). The Role of Technical and Vocational Education in Career Development. Journal of Technical, Vocational \& Engineering Education, 5, 28-34.

Johnson, B., \& Christensen, L. B. (2000). Educational Research: Quantitative and Qualitative Approaches. Boston, MA: Allyn and Bacon.

Johnson, D. R., Stodden, R., Emanuel, E., Luecking, R., \& Mack, M. (2002). Current Challenges Facing Secondary Education and Transition Services: What Research Tells Us. Exceptional Children, 68, 519-531. https://doi.org/10.1177/001440290206800407

Juairiah, J. (2000). Kajian perancangan dan pelaksanaan khidmat sokongan bagi kelas bermasalah pembelajaran di sebuah sekolah rendah di negeri Selangor Darul Ehsan. Latihan Ilmiah Sarjana Muda Pendidikan Khas. Bangi: Universiti Kebangsaan Malaysia.

Kiernan, W. E., \& Stark, J. A. (1989). Pathways to Employment for Adults with Developmental Disabilities. Baltimore, MD: Brookes.

Kohler, P. D. (1996). Taxonomy for Transition Programmeming: Linking Research to Practice. Champaign, IL: Transition Research Institute.

Kohler, P. D., \& Field, S. (2003). Transition-Focused Education: Foundation for the Future. The Journal of Special Education, 37, 174-183. https://doi.org/10.1177/00224669030370030701

Landmark, L. J., Ju, S., \& Zhang, D. (2010). Substantiated Best Practices in Transition: Fifteen Plus Years Later. Career Development for Exceptional Individuals, 33, 163-176. https://doi.org/10.1177/0885728810376410

Merriam, S. B. (2009). Qualitative Research: A Guide to Design and Implementation. San Francisco, CA: Jossey-Bass.

Morningstar, M. E., Bassett, D. S., Kochhar-Bryant, C., Cashman, J., \& Wehmeyer, M. L. (2010). Aligning Transition Services with Secondary Education Reform: A Position Statement of the Division on Career Development and Transition. Career Development and Transition Development for Exceptional Individuals, 35, 132-142.

https://doi.org/10.1177/2165143412454915

Noonan, P. M., McCall, Z. A., Zheng, C., \& Erickson, A. G. (2012). An Analysis of Collaboration in a State-Level Interagency Transition Team. Career Development and Transition for Exceptional Individuals, 35, 143-154. https://doi.org/10.1177/2165143412443083

Patton, M. Q. (2002). Qualitative Research and Evaluation Methods (3rd ed.). Thousand Oaks, CA: Sage Publications.

Ramlee, M. (2004). IT and Multimedia Literacy in Technical and Vocational Education in Malaysia. International Journal of Digital Contents, 2, 113-115.

Sanbagavalli a/p Subramaniam (2001). Kolaborasi antara ibu bapa dan guru kanak-kanak berkeperluan khas di sebuah sekolah menengah di Klang, Selangor. Kertas Projek. Kuala Lumpur: Universiti Malaya.

Shafie, L. (2002). Programme pendidikan khas di Sarawak: Satu penilaian. Tesis Dr Falsafah. Bangi: Universiti Kebangsaan Malaysia. 
Singley, S. G. (2003). Barriers to Employment among Long-Term Beneficiaries: A Review of Recent International Evidence. Centre for Social Research and Evalution.

Sitlington, P. L., \& Clark, G. J. (2006). Transition Education and Services for Students with Disabilities (4th ed.). Boston, MA: Allyn \& Bacon.

Taylor, A. (2005). What Employers Look for: The Skills Debate and the Fit with Youth Perceptions. Journal of Education and Work, 18, 201-218.

https://doi.org/10.1080/13639080500085984

US Commission on Civil Rights (1983). Attitudes toward the Handicapped. Washington DC: US Government Printing Office.

Wehman, P., Kregel, J., \& Barcus, M. M. (1985). From School to Work: A Vocational Transition Model for Handicapped Students. Exceptional Children, 52, 25-37. https://doi.org/10.1177/001440298505200103

Wehman, P., Kregel, J., \& Seyfarth, J. (1985). Transition from School to Work for Individuals with Severe Handicaps: A Follow-Up Study. Journal of the Association for Persons with Severe Handicaps, 10, 132-136. https://doi.org/10.1177/154079698501000302

Yin, R. K. (2008). Case Study Research: Design and Methods (5rd ed.) Newbury: CA: Sage Publications.

Zainudin, M. I. (2004). Peranan masyarakat dalam mempertingkatkan kerjaya golongan berkeperluan khas. Seminar Pendidikan Khas. Kejayaan Kanak-kanak Berkeperluan Khas: Perkongsian Bersama, 2, 402-406.

Zainudin, M. I. (2008). Analisis keperluan kurikulum pendidikan vokasional pelajar bermasalah pembelajaran peringkat menengah di Malaysia. Tesis Ph.D. Fakulti Pendidikan. Bangi: Universiti Kebangsaan Malaysia.

Zainudin, M. I., Noraini, S., \& Ramlee, M. (2009). Kurikulum pendidikan vokasional murid bermasalah pembelajaran (Mp). Digest Pendidik, 9, 89-99.

Zhang, D., Ivester, J., \& Katsiyannis, A. (2005). Teachers' View of Transition Services: Results from a State wide Survey in South Carolina. Education and Training in Developmental Disabilities, 40, 360-367. 